\title{
Mutations of Ki-ras and p53 genes in colorectal cancer and their prognostic significance
}

\author{
M Morrin, M Kelly, N Barrett, P Delaney
}

\begin{abstract}
The series of genetic changes leading to malignancy in colorectal cancer is well reported. This includes mutational activation of the proto-oncogene Ki-ras and mutation/deletion of the p53 tumour suppressor gene. The frequency of these mutations was investigated in a panel of 52 colorectal cancer patients using a combination of immunocytochemistry and non-radioactive, digoxigenin-labelled in situ hybridisation. Sixty two per cent (32 of 52) of the study population were positive for p53 overexpression and 36\% (19 of 52) positive for Ki-ras mutation. Twenty seven per cent (14 of 52) of the patients expressed both mutations. Mutation of either the p53 or the Ki-ras gene did not correlate with Dukes's stage, tumour differentiation or 5 year survival rate of the patients. Most of the rectal carcinoma specimens (11 of 15) showed p53 overexpression but the significance of this was not supported statistically. Thus detection of molecular changes is becoming more amenable to incorporation into routine histological carcinoma assessment because of the advent of nonradioactive labelling in in situ hybridisation and antibodies suitable for paraffin wax embedded specimens. The significance of these mutations in disease prognosis, however, remains questionable.
\end{abstract}

(Gut 1994; 35: 1627-1631)

Colorectal cancer is the result of an accumulation of genetic changes. These cancers are particularly well suited to studies of the progression of genetic changes leading to malignancy, as they tend to develop over years, if not decades. These acquired mutations affect fundamental cellular regulatory mechanisms, usually through the inactivation of tumour suppressor genes or the activation of oncogenes. These include the APC and MCC genes on chromosome $5 \mathrm{q} 21,{ }^{1-3}$ the DCC gene on chromosome $18,{ }^{4}$ the nm23 gene, ${ }^{5}$ the p53 gene on chromosome $17 \mathrm{p},{ }^{6}$ and the oncogenes $\mathrm{Ki}$-ras and c-myc. ${ }^{78}$

Evidence accrued to date shows that the p53 gene is the most commonly altered gene in human cancer, with mutations having been detected in breast, ${ }^{9}$ renal cell, ${ }^{10}$ oesophageal, ${ }^{11}$ and non-small cell lung cancer. ${ }^{12}$ It is a tumour suppressor gene, which in its normal form codes for a $53 \mathrm{kD}$ protein, which binds to DNA and acts as a transcription factor to halt cells in the $\mathrm{Gl}$ to $S$ transition in the cell cycle. ${ }^{13} 14$ Mutant forms lack this DNA binding activity and thus cannot halt replication when DNA has become damaged and needs extra time for repair. This is the basis of Lane's functional model of p53 as a 'molecular policeman'. ${ }^{15}$

Deletions of chromosome $17 p$ are found in $75 \%$ of colorectal cancers and are highly correlated with mutation of the remaining p53 gene. ${ }^{1617}$ These mutations can be detected by immunocytochemistry, as the normally short lived protein becomes stabilised. Overexpression of $\mathrm{p} 53$ protein has been found in 42 to $67 \%$ of colorectal carcinomas ${ }^{18} 19$ and is generally considered to be one of the later genetic changes in the adenoma-carcinoma sequence. $^{20}$

The ras gene family consists of three closely related genes, $\mathrm{H}$-ras, $\mathrm{N}$-ras, and $\mathrm{Ki}$-ras, which code for $21 \mathrm{kD}$ proteins. These proteins are localised to the inner plasma membrane and can exist in two states: an active, signal transducing, GTP-binding state and an inactive, GDP-containing state. ${ }^{21}$ Mutations in Ki-ras are the ones most commonly associated with colorectal cancer, ${ }^{7}$ where they result in the loss of GTPase activity, causing the cell to be continuously activated and locked into proliferation. The incidence of mutated $\mathrm{Ki}$-ras varies strongly among different tumour types, with only $4 \%$ of ovarian carcinomas showing an activated $\mathrm{Ki}$-ras gene, ${ }^{22}$ whereas $42-50 \%$ of colorectal carcinomas had this mutation. 2023

We wished to assess the relation between p53 and $\mathrm{Ki}$-ras mutations and their prognostic significance in a series of colorectal cancer patients, using methods that could be incorporated into routine histological carcinoma assessment, namely immunocytochemistry and non-radioactive in situ hybridisation, and possibly enhance the accuracy of the currently used prognostic staging systems.

\section{Methods}

TUMOUR SAMPLES

Formalin fixed, paraffin wax embedded tissue sections from 52 colorectal cancer patients treated at Limerick Regional Hospital from 1987 to 1988 were used in the study. The study population consisted of four Dukes's A, 23 Dukes's B, 11 Dukes's C, and 14 Dukes's $D$ patients. Of these tumours, 25 were left sided, 11 right sided, and 15 were rectal. When subdivided on the basis of differentiation, 27 of the tumours were well differentiated, 21 were moderately differentiated, and four were poorly differentiated. 


\section{IMMUNOCYTOCHEMISTRY}

Sections $(5 \mu \mathrm{m})$ were collected into poly-1lysine-coated slides, dewaxed in xylene, and rehydrated through graded alcohols. Endogenous peroxidase was blocked by incubation in $3 \%$ hydrogen peroxide solution (15 minutes). Normal rabbit serum at 1:5 dilution in TRIS buffered saline was used to block nonspecific binding. Sections were incubated with primary antibody (DO-7 mouse monoclonal antibody, specific for human wild type and mutant p53 protein, Dako Ltd, High Wycombe, UK) at 1:100 dilution in TRIS buffered saline, overnight at $4^{\circ} \mathrm{C}$. After incubation with a polyclonal biotinylated rabbit antimouse antibody (Dako Ltd, High Wycombe, UK) at 1:300 dilution in TRIS buffered saline for 40 minutes at room temperature, a StreptABComplex kit (Dako Ltd, High Wycombe, UK) with aminoethyl carbazole as chromogen was used to visualise the staining. Each section was incubated in the absence of primary antibody as a negative control. Tumours with strong p53 overexpression were used as positive controls.

\section{NON-RADIOACTIVE IN SITU HYBRIDISATION}

\section{cDNA probe preparation}

A cDNA probe, specific for the codon 12 mutation of the activated form of the human $\mathrm{Ki}$-ras 2 oncogene ${ }^{24}$ was isolated from clone ATCC 41027 according to standard techniques. ${ }^{25}$ The random primer labelling system $^{26}$ was used to label the cDNA probe with digoxigenin-11-dUTP (Boehringer Mannheim, Lewes, UK). The prime-a-gene labelling kit (Promega Corp, Madison, WI, USA) was followed according to the manufacturer's instructions but was modified to permit incorporation of digoxigenin instead of ${ }^{32} \mathrm{P}$ that is, the labelling mixture contained $1.5 \mathrm{mM}$ each of unlabelled dATP, dCTP, dGTP, 0.97 $\mathrm{mM}$ dTTP, and $0.53 \mathrm{mM}$ digoxigenin - 11dUTP. The rest of the protocol remained unchanged.

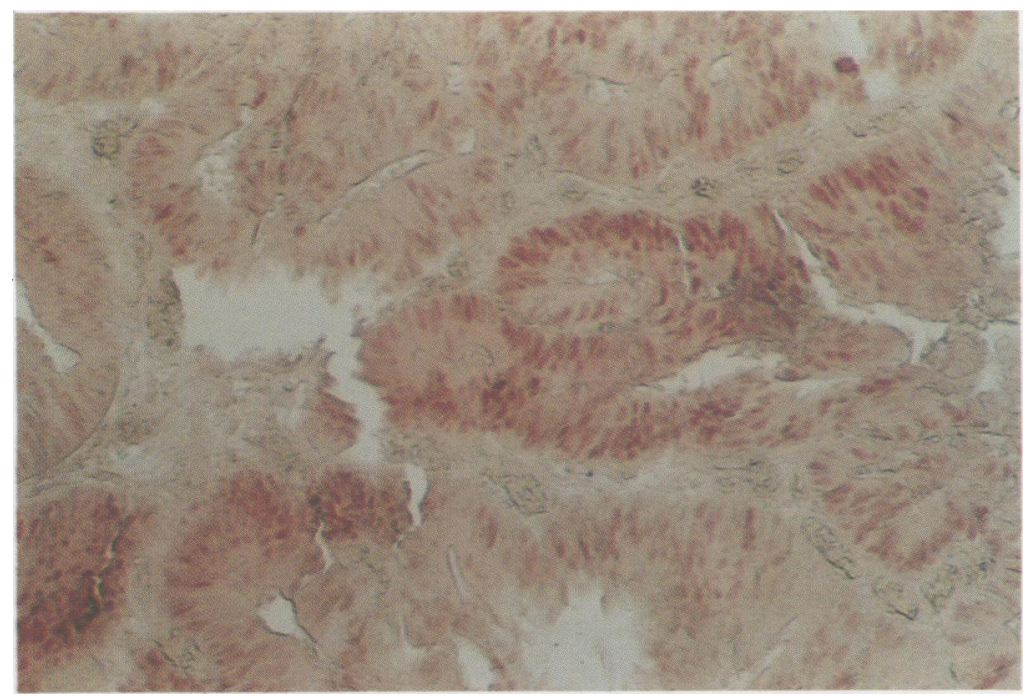

Figure 1: Demonstration of nuclear p53 overexpression by immunocytochemistry in a colorectal tumour specimen.
Tissue preparation/hybridisation protocol

All of the normal precautions taken with in situ hybridisation to prevent RNAase or DNAase contamination were used throughout the procedure - that is, baking of glassware, use of sterile reagents/containers, incorporation of diethylpyrocarbonate in buffers, etc.

Tissue specimens of $5 \mu \mathrm{m}$ were collected onto poly-l-lysine coated slides, dried overnight at $37^{\circ} \mathrm{C}$, dewaxed in xylene, and rehydrated through graded alcohols. After incubation in 10 $\mathrm{mg} / \mathrm{ml}$ solution of proteinase $\mathrm{K}$ in TRIS buffered saline at $37^{\circ} \mathrm{C}$, the slides were washed and then fixed in $4 \%$ paraformaldehyde solution in phosphate buffered saline at $4^{\circ} \mathrm{C}$. The tissue was subjected to a prehybridisation step by incubating with the hybridisation cocktail, minus the cDNA probe, for one hour at $42^{\circ} \mathrm{C}$. The cocktail consisted of $50 \%$ deionised formamide, $1 \times$ Denhardt's solution, $10 \%$ dextran sulphate, $10 \mathrm{mM}$ dithiothreitol, and $18 \%$ TRIS-EDTA buffer (10 mM TRIS- $\mathrm{HCl}, 1$

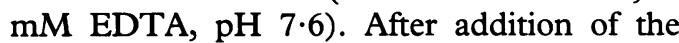
digoxigenin-labelled cDNA probe, the sections were denatured at $98^{\circ} \mathrm{C}$ for 10 minutes, placed on ice for two minutes, and then incubated overnight at $42^{\circ} \mathrm{C}$. Sections were washed next day in decreasing concentrations of SSC buffer ( $3 \mathrm{M} \mathrm{NaCl}, 0.3 \mathrm{M}$ sodium citrate, $\mathrm{pH} 7 \cdot 2$ ) and the bound probe detected by immunocytochemistry using the digoxigenin nucleic acid detection kit (Boehringer Mannheim, Lewes, UK) with nitroblue tetrazolium chloride and bromochloroindoylphosphate for localisation of bound, alkaline phosphatase labelled antibody. Controls comprised of (a) pretreatment with $100 \mathrm{mg} / \mathrm{ml}$ RNAase $\mathrm{A}$ in $2 \times \mathrm{SSC} / 10 \mathrm{mM} \mathrm{MgCl}$ for one hour at $37^{\circ} \mathrm{C}$ before hybridisation or (b) omission of labelled probe.

The efficacy of labelling was estimated by a dot blot technique where the response obtained from different concentrations of a labelled control DNA solution was compared with a dilution series of labelled cDNA probe. The response was detected using the reagents from the digoxigenin nucleic acid detection kit (Boehringer Mannheim).

\section{STATISTICAL ANALYSIS}

Frequency of p53 or Ki-ras positive tumours was compared for each variable using $\chi^{2}$ statistics with the Solo Statistical System (BMDP Statistical Software, CA, USA).

\section{Results}

Overexpression of p53 protein was detected immunohistochemically in 32 of $52(62 \%)$ of the tumour specimens examined. Staining was predominately nuclear and was rarely seen in adjacent normal mucosa (Fig 1). Activation of the $\mathrm{Ki}$-ras gene was detected using a digoxigenin-labelled cDNA probe by non-radioactive in situ hybridisation in 19 of $52(36 \%)$ of the study population. As the probe was specific for mRNA, specific staining was exclusively cytoplasmic in all tumour specimens examined (Fig 2). 


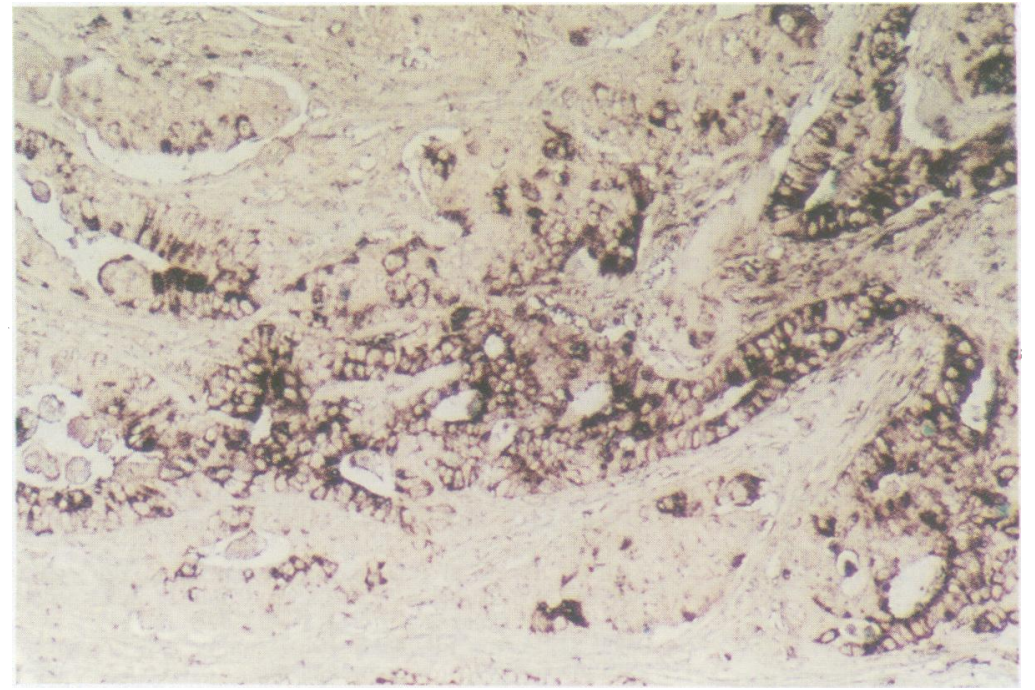

Figure 2: Detection of cytoplasmic mutated Ki-ras oncogene by in situ hybridisation in a colorectal tumour specimen. presentation with disease in the $\mathrm{Ki}$-ras positive population $(7(35 \%) v 9(45 \%)$ of 19$)$. None of the clinicopathological variables were found to correlate with the expression of either p53 or $\mathrm{Ki}$-ras mutations when analysed for statistical significance.

\section{Discussion}

Studies over the past five years have used various methods of detection to investigate p53 or Ki-ras mutations in colorectal cancer in an attempt to determine their prognostic significance. In a study using immunocytochemistry on frozen sections, Scott et al, ${ }^{19}$ reported that 22 of $52(42 \%)$ of their samples were positive for $\mathrm{p} 53$, but no correlation was found with Dukes's stage, tumour grade or patient survival. When flow cytometry was used to quantify nuclear attached p53,18 50 of 78 $(64 \%)$ of the samples contained high levels of $\mathrm{p} 53$. These high levels correlated with tumour site, $17 \mathrm{p}$ allele loss, hyperdiploid DNA content, and also survival, but only when the Dukes's D samples were included in the analysis. Other studies using immunocytochemistry on paraffin wax embedded tissue also found a correlation between p53 content and survival, 2728 but differed in their assessment of significance of Dukes's staging. The use of different antibodies and tissue preparation procedures influences the extent of staining in these various studies, as the epitope on the p53 protein that a particular antibody is directed towards may not survive the fixation procedure. The frequency of antibody reactivity varied from 64 to $36 \%$ when three p53 antibodies were compared in a study on 90 frozen tissue specimens. ${ }^{29}$ In general, however, there is quite good agreement between the different studies on the overall frequency of p53 overexpression, but to achieve statistical significance between this overexpression and some of the clinicopathological variables, a larger study population seems to be necessary. This is shown in our study, where the frequency of p53 positive tumours was similar to other reports - that is, $62 \%$ - but no correlation with Dukes's stage, tumour location, degree of differentiation or survival was established.

Mutations in the $\mathrm{Ki}$-ras oncogene are thought to occur at an early stage in the adenoma-carcinoma sequence, with the frequency of mutations increasing with adenoma size. ${ }^{20}$ In studies of Ki-ras mutation in gastrointestinal dysplasias, polymerase chain reaction amplification and sequence/restriction enzyme analysis of the mutated region seems to be the method of choice. ${ }^{23} 3031$ This technique may not be available, however, in every laboratory and thus many have used specific antibodies to investigate levels of the ras gene product, p21, as a marker of mutational activation, with the monoclonal antibody Y13-259 being one of the most commonly used probes. ${ }^{32-34}$ We felt that the efficacy of this and other antibodies on formalin fixed, archival material was questionable and wanted to develop a technique that could possibly be 
incorporated into routine histological carcinoma assessment, if it proved to be of prognostic significance. This is why an in situ hybridisation technique, using the nonradioactive label digoxigenin, was used to assess frequency of Ki-ras mutation. Thirty six per cent of the samples showed activation of the $\mathrm{Ki}$-ras gene, but a correlation with either Dukes's stage, tumour differentiation, tumour location or survival was not found. In a study comparing ulcerative colitis associated and sporadic colorectal carcinomas, 14 of 33 $(42 \%)$ of the sporadic cases were positive for $\mathrm{Ki}$-ras codon 12 mutation, with a significant association with a rectal location. ${ }^{23}$ Left sided tumour location is also frequently found to correlate with p53 overexpression, 1928 evidence that corroborates the theory of distinct patterns of tumour progression being associated with different sites in the colorectum.

Twenty seven per cent of the specimens studied here were positive for both p53 and $\mathrm{Ki}$-ras mutations. The survival rate for patients with both mutations was not significantly different from those with only one or neither of the mutations (data not shown). This is in contrast with the study of 100 colorectal tumours by Bell et $a l^{35}$ where the survival rate of patients expressing both mutations was nearly a third of that of the remainder of the series. It is not clear whether or not there is an association between the two types of mutation in tumour development. Enomoto et al ${ }^{36}$ report that ras and p53 gene mutations occur independently in endometrical adenocarcinoma. This was also seen in non-small cell lung cancer. ${ }^{37}$ In a mouse prostate model, the expression of activated ras and myc oncogenes induced carcinoma development but bypassed the need for p53 mutation by neutralising the tumour suppressor activity of normal p53.38 Cooperation between ras cDNA and mutant p53 was required, however, to fully transform rat embryo fibroblasts, as neither cDNA alone accomplished this to the same extent. ${ }^{39}$ To add further confusion, the presence of both p53 overexpression and $\mathrm{Ki}$-ras mutation was not sufficient to cause transformation of benign large bowel adenomas in two separate studies of these mutations in colorectal adenomas. ${ }^{40} 41$ It would seem that the in vivo situation and that seen in model systems differ quite significantly. Many factors other than mutations in p53 and Ki-ras genes determine the progression of disease (for example, mutations in the DCC, APC or nm23 genes, environmental factors, etc), thereby making the assessment of prognostic significance of the p53 and $\mathrm{Ki}$-ras mutations difficult. These other factors may be partially responsible for the differing survival rates reported for patients expressing both mutations (for example, ${ }^{35}$ this study). In our study there was no evidence to suggest that the presence of either or both mutations was prognostically less favourable or that either one occurs earlier or later in the progression of disease. Thus, even though techniques are now available that could be incorporated into routine histological carcinoma assessment, namely immunocytochemistry on paraffin wax embedded tissue and non-radioactive in situ hybridisation, the prognostic significance of these mutations remains questionable.

1 Bodmer WF, Bailey GJ, Bodmer J, Bussey HJR, Ellis A, Gorman P, et al. Localisation of the gene for familial adenomatous polyposis on chromosome 5. Nature 1987; 328: 614-6.

2 Leppert M, Dobbs M, Scambler P, O'Connell P, Nakamura $\mathrm{Y}$, Stauffer $\mathrm{D}$, et al. The gene for familial polyposis coli maps to the long arm of chromosome 5. Science 1987; 238: $1411-3$.

3 Kinzler KW, Nilbert MC, Su L, Vogelstein B, Bryan TM, Levy DB, et al. Identification of FAP locus genes from chromosome 5q21. Science 1991; 253: 661-5.

4 Fearon ER, Cho KR, Nigro JM, Kern SE, Simons JW, Ruppert JM, et al. Identification of a chromosome 18q gene that is altered in colorectal cancers. Science 1990; 247: 49-56.

5 Stahl JA, Leone A, Rosengard AM, Porter L, King CR, Steeg PS. Identification of a second human nm23 gene, nm23-H2. Cancer Res 1991; 51: 445-9.

6 Baker SJ, Fearon ER, Nigro JM, Hamilton SR, Preisinger AC, Jessop JM, et al. Chromosome 17 deletions and p53 gene mutations in colorectal carcinomas. Science 1989; 244: 217-21.

7 Forrester K, Almoguera C, Han K, Grizzle WE, Perucho $M$. Detection of high incidence of $\mathrm{K}$-ras oncogenes during human colon tumorigenesis. Nature 1987; 327: 298-303.

8 Maestro R, Viel A, Boiocchi M. Correlation between chromosome $5 q$ deletions and different mechanisms of c-myc overexpression in human colorectal cancer. Br f Cancer 1991; 63: 185-6.

9 Poller DN, Hutchings CE, Galea M, Bell JA, Nicholoson $\mathrm{RA}$, Elston CW, et al. p53 protein expression in human breast carcinoma: relationship to expression of epidermal growth factor receptor, c-erbB-2 protein overexpression, and oestrogen receptor. Br f Cancer 1992; 66: 583-8.

10 Reiter RE, Anglard P, Liu S, Gnarra JR, Marston Linehan W. Chromosome $17 \mathrm{p}$ deletions and p53 mutations in renal cell carcinoma. Cancer Res 1993; 53: 3092-7.

11 Huang Y, Meltzer SJ, Yin J, Tong Y, Chang EH, Srivasta S, et al. Altered messenger RNA and unique mutational profiles of p53 and Rb in human esophageal carcinomas. profiles of $\mathrm{p} 53$ and $\mathrm{Rb}$ in human
Cancer Res 1993; 53: 1889-94.

12 Horio Y, Takahashi T, Kuroishi T, Hibi K, Suyama M, Niimi T, et al. Prognostic significance of p53 mutations and $3 p$ deletions in primary resected non small cell lung cancer. Cancer Res 1993; 53: 1-4.

13 Hollstein M, Sidransky D, Vogelstein B, Harris CC. p53 mutations in human cancer. Science 1991; 253: 49-53.

14 Donehower LA, Bradley A. The tumour suppressors p53. Biochim Biophys Acta 1993; 1155: 181-205.

15 Lane DP. Guardian of the genome. Nature 1992; 358: $15-6$. 6 Baker SJ, Presinger AC, Jessop JM. p53 gene mutations occur in combination with $17 \mathrm{p}$ allelic deletions as late events in colorectal tumorigenesis. Cancer Res 1990; 50: 7712-7.

17 Scott N, Quirke P. Molecular biology of colorectal neoplasia. Gut 1993; 34: 289-92.

18 Remvikos Y, Tominaga O, Hammel P, Laurent-Puig P, Salmon RJ, Dutrillaux B, et al. Increased p 53 protein content of colorectal tumours correlates with poor survival. Br f Cancer 1992; 66: 758-64.

19 Scott N, Sagar P, Stewart J, Blair GE, Dixon MF, Quirke P. p53 in colorectal cancer: clinicopathological correlation and prognostic significance. Br f Cancer 1991; 63: 317-9.

20 Vogelstein B, Fearon ER, Hamilton SR, Kern SE, Preisinger AC, Leppert $M$, et al. Genetic alterations during colorectal development. $N$ Engl f Med 1988; 319:

21 Feig LA. The many roads that lead to ras. Science 1993; 260: 767-8.

22 Teneriello MG, Ebina M, Linnoila RI, Henry M, Nash JD, Park RC, et al. p53 and Ki-ras gene mutations in epithelial ovarian neoplasms. Cancer Res 1993; 53: 3103-8.

23 Bell SM, Kelly SA, Hoyle JA, Lewis FA, Taylor GR, Thompson $\mathrm{H}$, et al. cKi-ras gene mutations in dysplasia and carcinomas complicating ulcerative colitis. $B r \quad \mathcal{F}$ Cancer 1991; 64: 174-8.

24 Mc Coy MS, Bargman CI, Weinberg RA. Human colon carcinoma $\mathrm{Ki}$-ras 2 oncogene and its corresponding protooncogene. Mol Cell Biol 1984; 4: 1577-82.

25 Sambrook J, Fritsch EF, Maniatas T. Molecular cloning- $A$ laboratory manual. 2nd ed. Cold Spring Harbor: 1989.

26 Feinberg AP, Vogelstein B. A technique for radiolabelling DNA restriction endonuclease fragments to high specific activity. Anal Biochem 1983; 132: 6-13.

27 Yamaguchi A, Nakagawara G, Kurosaka Y, Nishimura G, Yonemura Y, Miyazaki I. p53 immunoreaction in Yonemura Y, Miyazaki I. p53 immunoreaction in
endoscopic biopsy specimens of colorectal cancer, and its endoscopic biopsy specimens of colorectal cancer, and its prognostic significance. Br F Cancer 1993; 68: 399-402.
28 Starzynska T, Bromley M, Ghosh A, Stern PL. Prognostic significance of p53 overexpression in gastric and colorecsignificance of p53 overexpression in gastric and
tal carcinoma. $B r f$ Cancer 1992; 66: 558-62.

29 Cunningham J, Lust JA, Schaid DJ, Bren GD, Carpenter HA, Rizza E, et al. Expression of p53 and 17p allelic loss in colorectal carcinoma. Cancer Res 1992; 52: 1974-80. 30 Suchy B, Zietz C, Rabes HM. K-ras point mutations in colorectal carcinomas: relation to aneuploidy and metastasis. Int $\mathcal{F}$ Cancer 1992; 52: 30-3. 
31 Meltzer SI, Mane SM, Wood PK, Resau JH, Newkirk C, Terzakis JA, et al. Activation of c-Ki-ras in human gastrointestinal dysplasias determined by direct sequencing of polymerase chain products. Cancer Res 1990; 50: 3627-30.

32 Going JJ, Anderson TJ, Wyllie AH. Ras p21 in breas tissue: associations with pathology and cellular localisation. Br F Cancer 1992; 65: 45-50.

33 Dati C, Muraca R, Tazartes O, Antoniotti S, Perroteau I, Giai $M$, et al. c-erbB-2 and ras expression levels in breast cancer are correlated and show a co-operative association with unfavourable clinical outcome. Int $\mathcal{F}$ Cancer 1991; 47: 833-8.

34 Walker RA, Wilkinson N. p21 ras protein expression in benign and malignant human breast. 7 Pathol 1988; 156: benign and

35 Bell SM, Scott N, Cross D, Sagar P, Lewis FA, Blair GE. Prognostic value of $\mathrm{p} 53$ overexpression and c-Ki-ras gene mutations in colorectal cancer. Gastroenterology 1993; 104: $57-64$.

36 Enomoto $T$, Fujita $M$, Inoue $M$, Rice JM, Nakajima $R$, Tanizawa $\mathrm{O}$, et al. Alterations of the $\mathrm{p} 53$ tumour suppressor gene and its association with activation of the c-Kras-2 protooncogene in premalignant and malignant lesions of the human uterine endometrium. Cancer Res 1993; 53: 1883-8.

37 Mitsudomi T, Oyama T, Gazdar AF, Minna JD Okabayashi K, Shirakusa T. Mutations of ras and p53 genes in human non small cell lung cancer cell lines and their clinical significance. Fournal of fapanese Surgical Society 1992; 93: 944-7.

$38 \mathrm{Lu} \mathrm{X}$, Park SH, Thompson TC, Lane DP Ras-induced hyperplesia occurs with mutation of $\mathrm{p} 53$, but activated ras and myc together can induce carcinoma without p53 mutation. Cell 1992; 70: 153-61.

39 Zambetti GP, Olsen D, Labow M, Levine AJ. A mutant p53 protein is required for maintenance of the transformed phenotype in cells transformed with p53 plus ras cDNA's. Proc Natl Acad Sci USA 1992; 89:

40 Scott N, Bell SM, Sagar P, Blair GE, Dixon MF, Quirke P. p53 expression and $\mathrm{K}$-ras mutation in colorectal adenomas. Gut 1993; 34: 621-4.

41 de Benedetti L, Varesco L, Pellegata NS, Losi L, Gismond $\mathrm{V}$, Casarino L, et al. Genetic events in sporadic colorectal adenomas: K-ras and 53 heterozygous mutations are not sufficient for malignant progression. Anticancer Res 1993; 13: $667-70$. 